\title{
Rune Carvers and Sponsor Families on Bornholm
}

\author{
Laila Kitzler Åhfeldt ${ }^{1}$ and Lisbeth M. Imer ${ }^{2}$ \\ ${ }^{1}$ (Corresponding author) Swedish National Heritage Board, PO Box 1114, 62122 Visby, Sweden (laila.kitzler.ahfeldt@raa.se) \\ ORCID: 0000-0001-8364-59-52 \\ ${ }^{2}$ Nationalmuseet, Frederiksholms Kanal 12, 1220 København K, Denmark (lisbeth.imer@natmus.dk) \\ ORCID: 0000-0003-4895-1916
}

\begin{abstract}
The runestones on Bornholm have for a long time aroused discussion due to their singular character and dating as compared to most runestones in other parts of Denmark. In this paper, the relations between sponsors and rune carvers have been investigated through analysis of the carving technique by means of the first 3D-scanning and multivariate statistical analysis ever carried out on the Danish runestone material. The results indicate that the carvers were attached to the sponsor families and that the carvers were probably members of those families. During the fieldwork, a fragment of a previously unknown runestone was documented in the church of St. Knud.
\end{abstract}

\author{
ARTICLE HISTORY \\ Received 09 April 2019; \\ Accepted 12 Sep- \\ tember 2019

\section{KEYWORDS} \\ Runestone; Bornholm; \\ 3D-scanning; Rune \\ carver; Sponsor; \\ Carving technique
}

\section{Introduction}

When the runestones of Bornholm were raised, the practice of erecting runestones had already decreased dramatically in other Danish areas, where the number of runestones had fallen to the same level as before around 965, when the king claimed to have introduced Christianity. After $c .1020$ we know of no more than 15-20 runestones in the old Danish territory, with the exception of Bornholm where we know that the period $c .1025-1125$ produced 40 runestones (Imer 2016, 282-284). The Bornholm runestones have greater linguistic and ornamental similarities to the runestone tradition of central Sweden in the eleventh century than to the Danish tradition, but there has long been debate about whether this is due to particularly close connections with areas in central Sweden or if the similarity perhaps mostly has to do with chronology. There are arguments both for and against, and it cannot be said that the issue has been resolved.

One question is whether the carvers came from outside and what connection they had to the families that raised the stones. The runestones can be grouped according to the kinship relations in the inscriptions and according to the ornamentation. The aim here is to investigate how these runestone groups and family groups coincide with the carvers' identity. A completely different source of evidence will be used here, namely the carving technique, which will be studied by 3D-scanning and multivariate statistical methods, following a method developed at the Archaeological Research Laboratory, Stockholm University (Kitzler Åhfeldt 2002) and further refined in various research projects (e.g. Kitzler Åhfeldt 2015, 2016).

During the fieldwork on Bornholm, an important discovery was made too, when the $3 \mathrm{D}$-scanning of a runic carving in St. Knud's church - whose authenticity had previously been in serious doubt - had the result that it could be read and authenticated (Eilsøe 2017; Kitzler Åhfeldt 2017; Imer and Kitzler Åhfeldt forthcoming).

\section{The Runestones of Bornholm}

At present there are 40 known runestones on Bornholm. The rune shapes and linguistic forms place them from the middle of the eleventh century until some way into the twelfth century (Imer 2015). Long ago Ludvig Wimmer assigned the majority of them to the latter half of the eleventh century and the start of the twelfth (Wimmer 1905, 186, 190; Olsen 1906, 30). Lilliane Højgaard Holm, who has recently re-examined the runestones of Bornholm 
from a linguistic viewpoint, believes that the orthography, vocabulary, and the Christian message speak in favour of this late date (Højgaard Holm 2014, 262). The presumed time of Christianisation has been an important benchmark, namely, around 1060 when Bornholm, according to an earlier view, was converted by Bishop Egino. Marie Stoklund, however, argues that the boundary is too narrow, Bornholm could have been Christianised earlier and runestones could have been erected both before and after the suggested period (Stoklund 2006, 372). Erik Moltke thought that Bornholm started raising runestones one generation after people in Denmark had stopped (Moltke 1976, 269), but this gap may have shrunk now that they can be dated earlier.

Many of the runestones saw the light of day during church restorations and rebuilding in the second half of the nineteenth century. When Østermarie church was demolished at the end of that century, no fewer than three runestones were found at different places in the medieval church building, and a fourth runestone was lying in the churchyard (Jacobsen and Moltke 1942, 449-454). The Bornholm stones, however, were regarded as the least interesting in Denmark. Wimmer notes that, unlike other Danish stones, they are flat and thin (Wimmer 1905, 183, 186-187). Also, it was considered remarkable that no runestones were raised on Bornholm during the time when many were being set up in Skåne. It was furthermore noted that the formulas 'had the stone carved' or 'had the stone raised' and the prayers resemble those on Swedish runestones (Olsen 1906, 30-31).

Judging by the preserved finds, runes were very sparsely used on Bornholm in the Viking Age and Middle Ages. Apart from the runestones, all that survives is, in principle, some metal foils with runes. The exceptions are the medieval font in Åkirkeby (DK Bh 30), which was imported from Gotland; a horizontal grave slab, Vestermarie 4 (Dk Bh 44), under which, according to the inscription, at least three persons were buried (Bæksted 1935, 49); and a few inscriptions on the church walls in Ibsker (Dk Bh 44) and Nyker (Dk Bh 32)(Moltke 1985, 432). However, as we know from other sites, runes may have been written on perishable materials, such as wood. The number of metal amulets with runes and minuscules is increasing each year as a result of the systematic metal detector surveys of ploughed- out settlement sites. According to Højgaard Holm $(2014,262)$, the runic foils were probably not made on Bornholm, but she does not engage in any further discussion or explanation of her thesis. Most recently, Lisbeth Imer and Rikke Steenholt Olesen have shown that most of the amulets that make sense linguistically were created by church people (Imer and Steenholt Olesen 2018, 154), indicating that Bornholm too had a (runic) writing culture in the late Viking Age and early Middle Ages.

\section{In Favour of Swedish Influence}

In order to understand the importance of the runestones on Bornholm, we need to consider the role they have played in earlier discussions about Bornholm, as an island community and its affiliations to other Scandinavian communities and contemporary power spheres. Earlier research proposed Swedish influence as the explanation for the late runestones on Bornholm. Marius Kristensen argued that naming practices linked the Bornholm runestones to those in Sweden, and that Bornholm was heavily influenced by Swedish rune carvers (Kristensen 1930, 155-156). Moltke cited similarities in ornamentation, in certain rune forms, and in the runic prayer 'God help his spirit and God's mother', which is common in Sweden but does not occur in Denmark (Moltke 1934, 17). Moltke believed that it was Swedes with a knowledge of runes, for example from Södermanland and Östergötland, who brought the runic art to Bornholm. Other areas mentioned in this connection are Öland, Gotland, and Uppland. The runic beasts on Bornholm indeed have great similarities to those in Middle Sweden. The Swedes, according to Moltke, had not only taught the runes but had also themselves raised runestones on Bornholm (Moltke 1976, $269,271)$. He said that, while the ornamentation shows that the people of Bornholm learned from Swedish rune carvers, the personal names suggest even closer influence (Moltke 1934, 19). Moltke even saw Swedish influence in the forms of certain runes (Moltke 1976, 269). A linguistic feature that has been considered to indicate that certain rune carvers had a Swedish background is the word retta 'to erect' on two runestones, Bodilsker 5 (DR 378) and Østerlarsker 1 (DR 397). This is unknown in 
Danish runic inscriptions except on Bornholm, but is most commonly found in Uppland (Højgaard Holm 2014, 269).

\section{Against Swedish Influence}

There may be explanations for the similarities between the runestones of Bornholm and those of central Sweden other than direct influence from Swedish rune carvers. One example is that, whereas the rune $\mathbf{0}$ and the diphthong ei in Danmarks $R u$ neindskrifter were regarded as examples of Swedish influence, especially on Bornholm, Stoklund states that these are also found on runic coins and could be explained as a feature used throughout the Danelaw (Stoklund 2006, 373). There are also finds from Schleswig and Lund with these features (Lerche Nielsen 1997, 69; Stoklund 2006, 373), which is, if anything, evidence that this is a chronological feature, since Svæinn Estridsen's runic coins and the finds from Schleswig and Lund are closer in time to the Bornholm runestones.

Højgaard Holm rejects the idea that the eleventh-century central Swedish expansion lay behind Bornholm's runestones and proposes other factors that speak against Swedish influence (Højgaard Holm 2014, 296). One feature that is claimed to suggest that Bornholm's runestones show Swedish influence is the formula läta 'to have (something done)' + a main verb meaning 'raise, carve, make'. Højgaard Holm, however, thinks that the formula with an auxiliary verb is rather an expression of chronology, as it occurs on a younger group of runestones and was initially an upper-class marker (Højgaard Holm 2014, 269). Moreover, the preposition at 'after', which is common around Lake Mälaren, appears to be unknown on Bornholm (Højgaard Holm 2014, 270).

Carvers' signatures have also been held up as a Swedish feature, but there are only two runestones with a carvers' signature on Bornholm, too few to allow us to speak of Swedish influence (Højgaard Holm 2014, 276-277). In opposition to Kristensen and Moltke, who argued that the names pointed directly towards Sweden (Kristensen 1930, 155; Moltke 1976, 269), Højgaard Holm thinks that a large share of them belong to the common store of Norse names, whereas some of the names are asso- ciated with old Danish provinces, examples being Hallvarðr, Bø̄si, Guðki, Sassurr, Svartr, Tōli, and possibly Fullugi (Højgaard Holm 2014, 295). Others are distinctively Bornholm names, for example, those with the first element Alf- and $\varnothing y$ - or Auðand those with the second element -gairR. Attested Bornholm names that are known in Swedish sources have an eastern orientation, that is to say, they are known from the provinces facing the Baltic, but there are few Bornholm names on Öland and Gotland (Højgaard Holm 2014, 295). The principle of naming people after earlier generations was still alive on Bornholm in the eleventh century. Kristensen $(1930,155)$ held the view that Bornholm adopted this principle from Sweden, but Højgaard Holm sees Bornholm as a relict area for an old naming tradition. The tradition persisted longer in the east Norse than the west Norse area (Højgaard Holm 2014, 293). Michael Lerche Nielsen (1994, 176177) has nevertheless shown in an earlier work that traditions of naming people after past generations were widespread throughout the Danish area in the Viking Age.

\section{In Favour of the Danish realm}

Instead of viewing Bornholm's runestones as a result of Swedish influence, others have seen them as indications that Bornholm was incorporated in the Danish realm. Klavs Randsborg discusses the distribution of runestones in the light of centralisation. He believes that the Danish realm was largely united under King Svæinn Estridsen, possibly with the exception of Bornholm and Blekinge (Randsborg 1980, 33; cf. Wagnkilde and Pind 1989-1990, 64). Bornholm's runestones are assumed to belong together with Christianisation and the incorporation of Bornholm in the Danish administration after the middle of the eleventh century (Randsborg 1980, 44). Thegns and drengs are concentrated in southwest Bornholm, which is suggested to be due to royal vassals being found only in that part of the island. Randsborg goes on to interpret the large number of Bornholm runestones raised to women as being a consequence of newcomers marrying the daughters of Bornholm magnates (Randsborg 1980, 44). As regards this interpretation, one should note that there are only three runestones on Bornholm that men- 
tion the title 'dreng', and only one with a mention of a 'thegn'. These few runestones can hardly form a basis on which to make too far-reaching conclusions on the political situation and the royal power.

\section{Against the Danish Realm}

Randsborg has been criticised by runologists for drawing excessively far-reaching conclusions based on the distribution of the runestones, since he believes that they reflect the consolidation phase of royal power. Michael Lerche Nielsen asserts that the distribution can be heavily affected by how people in different areas reused them as building material, and by the now antiquated division into Pre-Jelling, Jelling, and Post-Jelling stones, which should rather be considered as relative typological groups (Lerche Nielsen 1997, 6 with further reference to Stoklund 1991, 295-296).

Bornholm's incorporation into the Danish realm has been assumed to have taken place sometime between the tenth century and the end of the eleventh century, with varied dates proposed by different researchers (Randsborg 1980; Watt 1985; Wienberg 1986: 45-46; Wagnkilde and Pind 1991; Nielsen 1998; for summaries of arguments, see Lihammer 2007, 242 and Gelting 2012: 107-10). Michael Gelting believes that elements in the Slesvig Stadsret and Knytlingasaga contradict that Bornholm was a part of Denmark in Egino's time (Gelting 2012: 109-10). Anna Lihammer for her part thinks that there is too little evidence of this, and that it did not occur until near 1100 (Lihammer 2007, 262). Lihammer's argument against Bornholm having been part of the Danish realm earlier than this is, among other things, that the ecclesiastical structure differs from that in western Denmark and that the archaeological circumstances indicate that conversion to Christianity took place from below. All in all, Lihammer thinks that there are no signs of belonging to Denmark in the eleventh century, as the first certain note of Danish royal power comes with twelfth-century Lilleborg (Lihammer 2007, 260-261, 273). In that chronological perspective the runestones need not be viewed in a specific Danish context.

Numismatic studies by Cecilia von Heijne show that the content of Bornholm's silver hoards differs from comparable hoards in Denmark at the time around 1100 and that they show instead much greater similarities to Blekinge's silver hoards (von Heijne 2004, 166). The hoards are dominated by foreign coins and include many non-monetary objects (von Heijne 2004, 152-156; Ingvardson 2010, 20). The prolongation of the weight economy and the lack of Danish coins for much of the period up to the thirteenth century shows that Bornholm was not integrated in Denmark's monetary system, which can also be interpreted to mean that the island was not wholly integrated in the Danish realm (Lihammer 2007, 292; Horsnæs 2013, 42). A survey of all the hoards shows that Bornholm's economic system differs greatly from that in the Danish kingdom and that Bornholm in the late Viking Age was still an independent economic and political unit (Ingvardson 2014, 329, 335). Bornholm never acquired a mint of its own, it lacked urban centres, and settlement was decentralised in single farms and small villages. Runestones on Bornholm bear few titles and, like the silver, they are scattered over the whole island, which is said to suggest a flat power structure and a decentralised trade structure (Nielsen 1994, 125129; Ingvardson 2010, 334-345).

\section{The Christianisation of Bornholm}

The runestones of Bornholm are also related to the discussion of Christianisation. Moltke believed that the runes came to Bornholm when the island was converted to Christianity by the bishop Egino in Dalby around 1060 (Moltke 1976, 269). It has also been suggested that the mission to Bornholm could have taken place in connection with the incorporation of the island in the Danish realm under Svæinn Estridsen (Randsborg 1980; Wagnkilde and Pind 1991, 64). The picture of Christianisation, however, is different in more recent research. Graves oriented east-west are found from the late tenth century (Watt 1983, 30-33). The mortuary practice in the Viking Age is said to be relatively distinctive and uniform on the island, but it changed around 1000 . Four early Christian burial places can be named in particular: Slamrebjerg, Munkegård, Runegård, and Grødbygård; they are all from the eleventh century, and with their mixture of Christian and pre-Christian burial traditions they show different stages of Christianisation (Svanberg 2003, 149; Lihammer 
$2007,247,250)$. There is a large element of grave goods and Slavic features in the graves.

\section{The Problem}

As we have seen, several earlier assumptions about Bornholm have recently been questioned, namely, whether the runestones suggest Swedish or Danish influence, the late conversion of Bornholm, and the strategic position of the island. It seems to be clear, however, that some change occurred in the eleventh century. Analyses of weights, hoards, and Baltic pottery show that there was a noticeable change in the organisation of settlement and trade on Bornholm around 1000 (Ingvardson 2014, 334).

Whereas some scholars argue that the similarity of the Bornholm runestones to those in central Sweden is primarily a chronological feature (Lerche Nielsen 1997; Højgaard Holm 2014; Imer 2016), not everyone appears to be convinced. For example, the similarities in ornament appear far too great to be wholly independent of each other (Gräslund 2016, 184-185).

These questions have not been resolved, as was obvious from the discussions at the international field runologists' meeting on Bornholm in 2015, arranged by Lisbeth Imer of the National Museum of Denmark and Rikke Steenholt Olesen of the University of Copenhagen. Rather than choose between Swedish influence and chronology, a Baltic tradition is emphasised, with the Baltic islands being part of the same cultural sphere as eastern Svealand. Other parameters include, for example, settlement history, with row-villages in Uppland and on Öland. Something happened to the language on Bornholm, however, as is obvious on the runestones. There is also a large span in the forms of the runes. Moltke's interpretation of the situation was that the written language was in a state of dissolution or development, as manifested in new runes, linguistic forms, and spelling variants, with a mixture of old and new (Moltke 1976, 279-280).

The archaeological issues, on the other hand, were discussed at a workshop in Visby in 2017 with archaeologists, runologists, and numismatists, when we dwelt on the question of Bornholm's presumed strategic position along the trade routes. ${ }^{1}$ This was questioned by the numismatists; at any rate the peo- ple of Bornholm do not appear to have made very much of it during the Viking Age.

\section{Questions}

As seen above, the runestones of Bornholm take a prominent place in important research issues concerning Bornholm's political status and Christianisation. They have been scrutinized from the perspectives of runology, ornament and archaeological context. We suggest that part of the problem concerning the rune carvers of Bornholm can be approached from a different angle, namely, the carving technique. In the following we will look more closely at the rune carvers in one context on Bornholm and their relationship to the families that sponsored the raising of the stones.

In this article we primarily discuss internal relations on Bornholm. The important question of whether the rune carvers were in contact with any part of Sweden is considered elsewhere (Kitzler Åhfeldt 2019), and will only be mentioned briefly below.

\section{The Study}

The fieldwork for the study was performed during a week in September 2017, when eight runestones underwent 3D-scanning by the company s3Di using Artec Eva and Artec Spider (Figure 1). The runestones were selected to represent some different groups linked by family relations, ornamentation, or distinctive runological features. We want to examine how these runestone groups and family groups coincide with carver identity. By carver identity, we here mean the handcrafter who made the actual stone cutting work. The rune carvers can be considered the first carriers of literacy in a generally oral society. Probably, they were much sought after for their special competence and their contacts and travels may tell us something about social interactions and networks. On the local level, the relations between the rune carvers may indicate kinship and friendship among families and households; across regions the presence of rune carvers may indicate networks and alliances on a larger scale. This made it desirable to include also runestones with ornamentation, pri- 


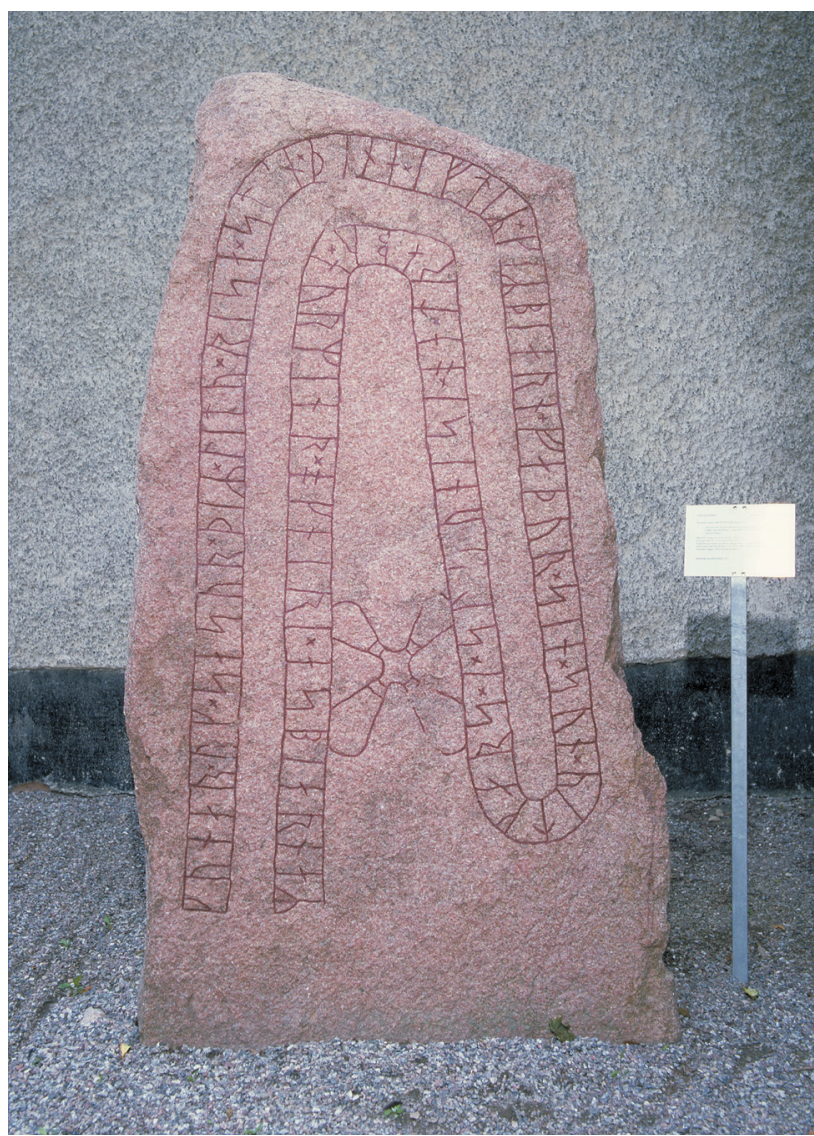

Figure 2. The Fresta stone $U$ 258. Photo: Bengt A Lundberg 1986, CC/BY Swedish National Heritage Board.

marily runic animals, which can be classified according to Anne-Sofie Gräslund's runestone chronology (Gräslund 2006) and which display similarities to many Swedish stones.

Three stones are of sandstone and five of granite (Andersen 1992; database Danske Runeindskrifter). These are:

Nylarsker 1 (DR 379, DK Bh 33). Sandstone. The inscription order on Nylarsker 1 has parallels in Sweden, e.g. Ög 129 (Moltke 1934, 17). Judging by closely related rune forms, especially the $\mathbf{s}, \mathbf{t}$, and $\mathbf{r}$ forms, Nylarsker 1 and Nylarsker 2 may belong to the same carver school, while the ornament resembles Nyker (Jacobsen and Moltke 1942, 435).

Nylarsker 2 (DR 380, DK Bh 34). Sandstone. According to Moltke the writing order resembles what one can see on Swedish stones, e.g. the older Fresta stone in Uppland (Moltke 1976, 277; U 258; Figure 2) and in Moltke's view it probably comes from the same workshop as Nylarsker 1, despite typological differences in the inscriptions (Jacobsen and Moltke 1942, 438).
Nyker (DR 389, DK Bh 31). Sandstone. Nyker has been assumed to have been made by the same carver as Vester Marie 5, Nylarsker 1 and Nylarsker 2 (Moltke 1976, 274). According to Moltke, Nyker resembles Nylarsker 1 in the ornamentation and $\mathrm{Ny}$ larsker 2 in the irregular rune forms, with the slightly rounded twig of the t-rune. Lis Jacobsen and Erik Moltke call this carver Træbene-Sønne and also ascribes Østermarie 3 to the same carver (Jacobsen and Moltke 1942, 934-935). It should be noted though, that this supposed carver name is due to an older interpretation of the inscription on Vestermarie 5, where the runic sequence trebin : u:syni was interpreted as Træbene-Sønne. However, this is now interpreted as 'shamefully killed' (Moltke 1985, 332). In Danmarks Runeindskrifter the Nyker stone is dated 1075-1125 (based on Bishop Egino's claim to have Christianised Bornholm), whereas Gräslund's typology of runic animals would set an earlier closing date, c. 1075-1100, Pr4 (Gräslund 2006). At the field runologists' meeting in 2015 the form pensa in the inscription was held up as something unusual in southern Scandinavia. Once again it was noted (as by Moltke) that the carver uses a strange $\mathbf{t}$-rune with the twig drawn as a single line. There was discussion as to whether the distinctive features of the Nyker stone are due to Swedish influence or to chronology.

Østermarie 2 (DR 391, DK Bh 52). Greyish, medium-grain granite. Partly the same names in the inscription as on Østermarie 3, but they look different.

Østermarie 3 (DR 392, DK Bh 53). Greyish granite. This stone is said to have Swedish features (Jacobsen and Moltke 1942, 451-452). Moltke finds parallels to the propeller-shaped cross in Östergötland (e.g. Ög 87, Ög 203, Ög 244) and Södermanland (Moltke 1934, 18). Østermarie 3 is very likely to be younger than Østermarie 2 , since yet another brother has been added and one brother has now died.

Klemensker 1 (DR 399, DK Bh 1), 'The Gunnhildr stone'. Reddish granite. The expression 'in light and paradise' occurs on Swedish stones (Jacobsen and Moltke 1942, 458; U 160, U 719 and possibly on Öl 51).

Klemensker 4 (DR 402, DK Bh 4). Reddish granite. $\operatorname{Pr} 2$, where the stone is dated to $c .1020-1050$ according to Gräslund's chronology (Gräslund 2006).

Knudsker (DK Bh 69). This stone was first authenticated in 2017, thanks to the 3D-scanning 


\begin{tabular}{|c|c|c|c|c|}
\hline Name & Picture & $\begin{array}{l}\text { English translation } \\
\text { (from SRD) }\end{array}$ & Transliteration & $\begin{array}{l}\text { Grouping } \\
\text { according to } \\
\text { Jacobsen and } \\
\text { Moltke } 1942 \\
\text { and Moltke } \\
1985\end{array}$ \\
\hline $\begin{array}{l}\text { Nylarsker } 1 \\
\text { DR } 379\end{array}$ & & $\begin{array}{l}\text { Sassurr had the } \\
\text { stone raised in } \\
\text { memory of Hall- } \\
\text { varðr, his father, } \\
\text { (who) drowned } \\
\text { abroad with all the } \\
\text { seamen. May Christ } \\
\text { ever (and) endless- } \\
\text { ly(?) help his soul. } \\
\text { May this stone stand } \\
\text { in memory. }\end{array}$ & $\begin{array}{l}\text { sasur : lit : resa : } \\
\text { sten : eftir : alu- } \\
\text { arp : fapur : sin } \\
: \text { truknapi : han } \\
: \text { uti : mep : ala : } \\
\text { skibara : etki : i : } \\
\text { kristr : ha-b siolu } \\
\text { has sten : pesi : } \\
\text { stai : eftir }\end{array}$ & Group 1 \\
\hline $\begin{array}{l}\text { Nylarsker } 2 \\
\text { DR } 380\end{array}$ & & $\begin{array}{l}\text { Svæinn (the Hood- } \\
\text { ed? son of Kāpa?) } \\
\text { raised this stone in } \\
\text { memory of Bø̄si, his } \\
\text { son, a good drangr, } \\
\text { who was killed in } \\
\text { battle at Uttlengia. } \\
\text { May Lord God and } \\
\text { Saint Michael help } \\
\text { his spirit. }\end{array}$ & $\begin{array}{l}\text { kobu:suain : raisti } \\
: \text { stain : p(e)na : } \\
\text { a(f)tir : bausa : } \\
\text { sun : sin : tr(i)... } \\
\text {..n : pan : is : } \\
\text { tribin : ua(r)p : i : } \\
(\text { u)(r)ostu : at : ut: } \\
\text { la(n)(k)iu : kup : } \\
\text { tr(u)tin : hi(a)lbi : } \\
\text { hans : ont : auk : } \\
\text { sata : mikial : }\end{array}$ & Group 1 \\
\hline $\begin{array}{l}\text { Nyker } \\
\text { DR } 389\end{array}$ & & $\begin{array}{l}\text { To... had this stone } \\
\text { raised in memory of } \\
\text { Svæinn, his son. A } \\
\text { very good drengR, ... } \\
\text {... and (in memory } \\
\text { of) his brother. May } \\
\text { holy Christ help the } \\
\text { souls of both these } \\
\text { brothers. }\end{array}$ & $\begin{array}{l}\text { (t)o... [l](e)t : resa } \\
\text { : sten (:) pensa : } \\
\text { eftir : suen : sun : } \\
\text { sin : trenkr al(g) } \\
\text { opar ...una(u)i ok } \\
\text { hans (:) (b)r(o)(b) } \\
\text { (u)r : krist : helgi } \\
\text { hal(b)(i) siolu : } \\
\text { pera :: brypra : } \\
\text { be(g)ia : }\end{array}$ & Group 1 \\
\hline
\end{tabular}




\begin{tabular}{|c|c|c|c|}
\hline $\begin{array}{l}\text { Østermarie } 2 \\
\text { DR } 391\end{array}$ & $\begin{array}{l}\text { Barni/Biarni and } \\
\text { Sibbi and Tōfi they } \\
\text { raised (the) stone in } \\
\text { memory of Ketill, } \\
\text { their father. May } \\
\text { Christ help his soul. }\end{array}$ & $\begin{array}{l}\text { barni : auk : sibi } \\
: \text { auk -ofi : peir : } \\
\text { reistu : sd } \\
\text { ei(n) (:) (e)ftir : } \\
\text { ke(t)(i)l : fapur sin } \\
:(k) \text { ristr (:) (h)lbi } \\
\text { hns siol : }\end{array}$ & Group 2 \\
\hline $\begin{array}{l}\text { Østermarie } 3 \\
\text { DR } 392\end{array}$ & $\begin{array}{l}\text { Barni/Biarni and } \\
\text { Töfi and Āsgautr } \\
\text { had (the) stone } \\
\text { raised in memory of } \\
\text { Sibbi, their brother. } \\
\text { May Christ help } \\
\text { (his) soul. }\end{array}$ & $\begin{array}{l}:(b) \operatorname{ar}(n) i: \text { auk : } \\
\text { tofi : ok : askutr } \\
: \text { letu : resa : sten } \\
: \text { eftir : siba : (b) } \\
\text { ropor : sin : krist : } \\
\text { sil : ia(l)bi }\end{array}$ & Group 2 \\
\hline $\begin{array}{l}\text { Klemensker } 1 \\
\text { DR } 399\end{array}$ & $\begin{array}{l}\text { Gunnhildr had } \\
\text { this stone raised in } \\
\text { memory of Auðb- } \\
\text { jgrn, her husband- } \\
\text { man. May Christ } \\
\text { help Auðbjgrn's } \\
\text { soul into light } \\
\text { and paradise. May } \\
\text { Christ and Saint } \\
\text { Michael help the } \\
\text { souls of Auðbjgrn } \\
\text { and Gunnhildr into } \\
\text { light and paradise. }\end{array}$ & $\begin{array}{l}(\mathrm{k})(\mathrm{u})(\mathrm{n}) \text { iltr }: \mathrm{l}(\mathrm{e}) \\
\mathrm{t}: \mathrm{r}(\mathrm{e}) \text { isa }: \text { st(e) } \\
\mathrm{n}: \mathrm{b}(\mathrm{e}) \mathrm{n}(\mathrm{s})(\mathrm{a}): \\
\text { eftir }: \text { aupbiarn : } \\
\text { bonta }: \text { sin : kristr } \\
: \text { hialbi : siolu : } \\
\text { aupbiarnar : i lus } \\
: \text { auk : bratis kris- } \\
\text { tr : hialbi : siolu : } \\
\text { (a)(u)(b)biarnar : } \\
\text { auk : ku(n)(i)(l)(t) } \\
\text { (a)(r) : auk : santa } \\
\text { mikel : i lius : auk } \\
: \text { baratis }\end{array}$ & \\
\hline $\begin{array}{l}\text { Klemensker } 4 \\
\text { DR } 402\end{array}$ & $\begin{array}{l}\text { Øylakr had this } \\
\text { stone raised in } \\
\text { memory of Sassurr, } \\
\text { his father, a good } \\
\text { husbandman. May } \\
\text { God and Saint Mi- } \\
\text { chael help his soul. }\end{array}$ & $\begin{array}{l}\text { : aulakr : let : } \\
\text { reisa : stein : pana } \\
: \text { eftir : sasur : } \\
\text { fopur sin : bonta : } \\
\text { kupan : kup : hi- } \\
\text { albi : siol : hans : } \\
\text { auk : sata : mihel : }\end{array}$ & Group 2 \\
\hline
\end{tabular}




\begin{tabular}{|l|l|l|l|l|}
\hline Knudsker & $\begin{array}{l}\text {... May Christ help } \\
\text { the soul (?)... }\end{array}$ & $\ldots$ & ..tr : ialb(i) (:) \\
(s)... & & \\
& & & & \\
& & & & \\
\hline
\end{tabular}

Figure 1. Fact box: Runestones in the investigation. 3D-scanned in September 2017. Photo: Roberto Fortuna, National Museum of Denmark, CC-BY-SA. 3D-image: The new find in St. Knud. 3D-scanning by Teddy Larsson, S3Di; picture by Laila Kitzler Åhfeldt 2017.

(Figure 1; Eilsøe 2017; Kitzler Åhfeldt 2017; Imer \& Kitzler Åhfeldt, forthcoming). The runestone fragment is incorporated in the wall above the door leading from the late medieval porch into the nave, in other words, over the original entrance to the church (Figure 3). In Danmarks Kirker the stone is said to be of yellowish granite (Danish 'gullig granit'), but it is not perceived by the editors as a runestone (Norn, Schultz, and Skov 1954, 184-185). The extant runes ...tr : ialb(i) (:) (s)... are part of a Christian prayer, 'May Christ help (the soul)'.

\section{Method}

The eight runestones mentioned above have been analysed by a method for groove analysis on runestones that was first developed at the Archaeological Research Laboratory at Stockholm University (Kitzler Åhfeldt 2002) and has been used in several recent studies to examine different problems. From the high-resolution 3D-models, we have excerpted a number of variables (Figure 4), describing different properties of the grooves, with the aid of special software $^{2}$ designed for the purpose. These variables are employed to study similarities and differences between the grooves on different runestones, different parts of the same carving, and also to investigate relations between, for example, certain monument groups or geographical areas. That part of the analysis can be varied and it is under continuous development (e.g. Kitzler Åhfeldt 2012; 2015; 2016). Like many other laboratory methods, it functions best if the results are discussed in relation to previous stud-

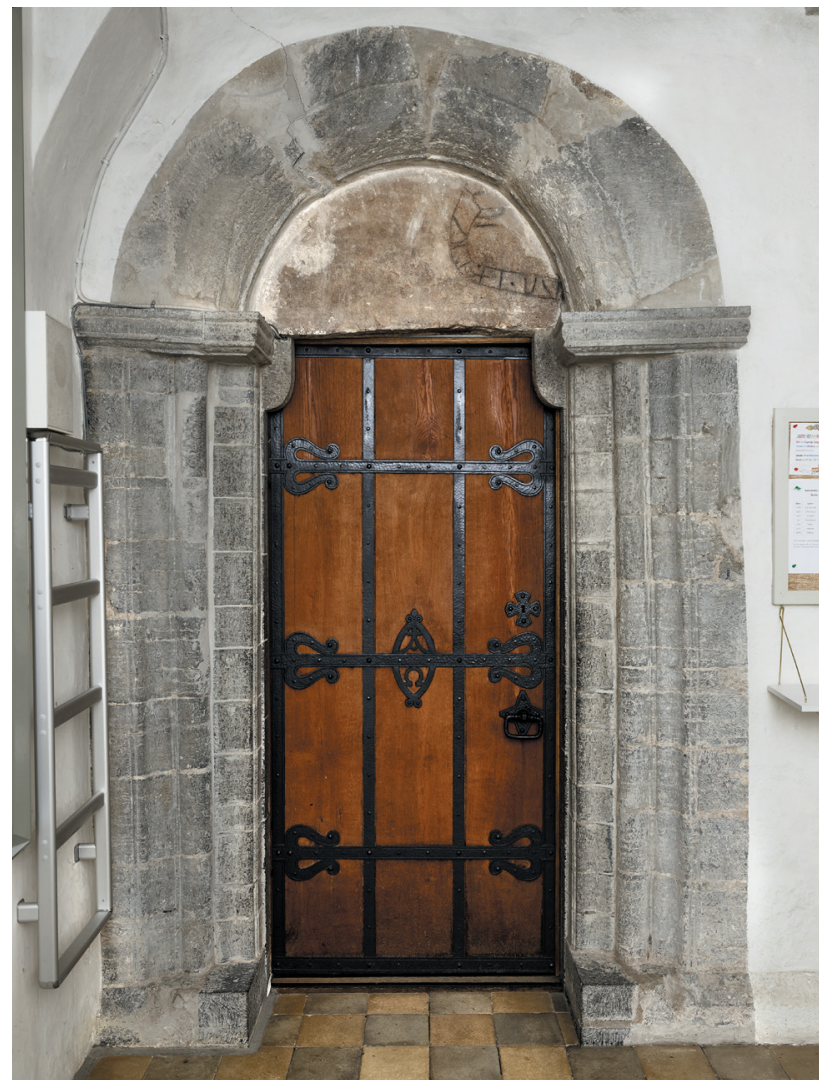

Figure 3. The runestone Knudsker above the door leading from the late medieval porch into the nave. Photo: Roberto Fortuna 2019, National Museum of Denmark CC-BY-SA.

ies and other indications, in an archaeological and runological discourse.

On each runic inscription, we have selected a number of runes and parts of the ornamentation. From Bornholm there is a total of 253 samples, 151 of which are runes and 102 ornamental details (runic bands, crosses; Table 1). In further steps of this spe- 

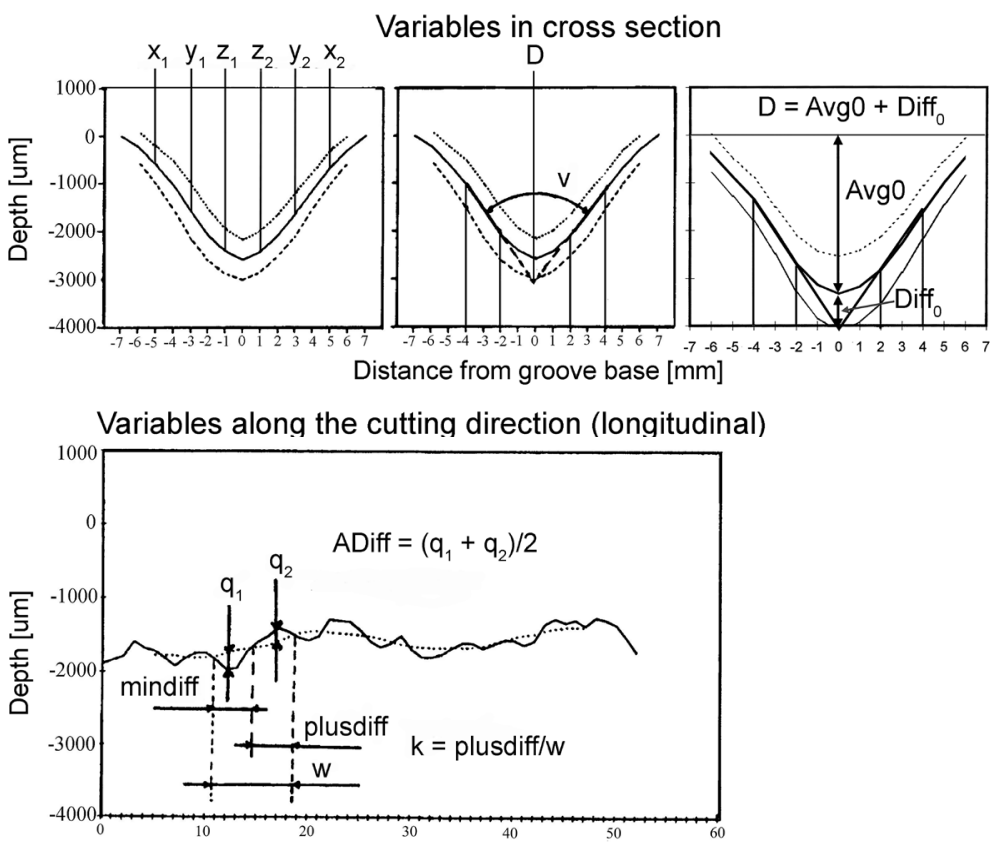

cific analysis, each runestone is represented by two mean values, one for the runes and one for the ornament and the variables used are v, D, k, w (Figure 4).

The runestones were analysed with multivariate statistical methods in STATISTICA 9. Hierarchical cluster analysis (Cluster Analysis, CLU) is used here, with Ward's method and Euclidean distances. Cluster analysis is about detecting groups in data (in artificial intelligence this is also called unsupervised pattern recognition) (Everitt et al. 2011, 7). Cluster analysis can be performed according to different algorithms that have slightly different properties and thus can give different results; for a discussion of these see e.g. Michael Baxter (2016). The cluster analysis begins with standardisation of the variables, which gives them the same weight in the analysis even if they are in different units and of different size (Baxter 2016, 54).

Multivariate analyses in general look for patterns in data, but different choices can be made among the calculation algorithms and the material to be included, and the results will be affected by this. We may mention briefly that the choices made here are based on results obtained in previous methodological studies and grounded in empirical material. For the theoretical reasoning behind multivariate analyses and applied statistics, readers are referred to works on statistics concerning archaeological material (e.g. Baxter 2016).
Figure 4. Variables for analysis of carving technique. Drawing: Laila Kitzler Ånfeldt.

$$
\begin{aligned}
& \frac{\operatorname{Avg}}{\operatorname{Avg}+\text { Std }} \\
& \hdashline \text { Avg-Std } \\
& \operatorname{AvgX}=\left(x_{1}+x_{2}\right) / 2 \\
& \operatorname{AvgY}=\left(y_{1}+y_{2}\right) / 2 \\
& \operatorname{AvgZ}=\left(z_{1}+z_{2}\right) / 2
\end{aligned}
$$

\section{Relations within Bornholm}

As we saw above, some of the runestones in the sample were presumed to be made by the same carver on account of similar rune forms or ornamentation. The first group consists of Nylarsker 1 (DR 379), Nylarsker 2 (DR 380), and Nyker (DR 389). Due to similarities in rune forms and ornament, Moltke suggested that they belonged to the same carver or workshop (see above; Group 1 in Table 1 and Figure 1). The second group include Østermarie 2 (DR 391), Østermarie 3 (DR 392), and Klemensker 4 (DR 402; see above; Jacobsen and Moltke 1942; Group 2 in Table 1 and Figure 1). The two first partly mention the same names, while Klemensker 4 are connected to them by certain rune forms (Jacobsen and Moltke 1942, 935;). Klemensker 1 and Knudsker have no obvious connections to the other stones in the sample. Can this grouping be confirmed by similarities in carving technique or will other relations emerge?

The result of the cluster analysis falls out differently, as is shown in a tree diagram (Figure 5). The runestones appear to fall into three groups and they reveal something interesting. The result differed from what we expected because the runestones are not grouped according to the forms of the runes, nor the ornamentation, but according to the names of the individuals who raised the stones:

1) Sassurr is sponsor (DR 379) or father to the sponsor (DR 402). DR 399 is joined to this group (Figure 6). 


\begin{tabular}{|c|c|c|c|c|c|c|c|}
\hline Name & $\begin{array}{l}\text { Signum in } \\
\text { SRD }\end{array}$ & $\begin{array}{l}\text { Entry in } \\
\text { Danske } \\
\text { Rune- } \\
\text { indskrifter }\end{array}$ & Style $^{1}$ & Comment in SRD ${ }^{2}$ & Grouping $^{3}$ & $\begin{array}{l}\text { Rock art } \\
\text { type }\end{array}$ & $\begin{array}{l}\text { Analyzed } \\
\text { runes/ } \\
\text { sections of } \\
\text { ornament }\end{array}$ \\
\hline Nylarsker 1 & DR 379 & DK Bh 33 & $\operatorname{Pr} 3$ & $\begin{array}{l}\text { Possibly the same } \\
\text { carvers as in DR } 372 \text {, } \\
380,387 \text { and } 389\end{array}$ & Group 1 & Sedimentary & $25 / 23$ \\
\hline Nylarkers 2 & DR 380 & DK Bh 34 & RAK & $\begin{array}{l}\text { Possibly the same } \\
\text { carvers as in DR } 372 \text {, } \\
379,387 \text { and } 389\end{array}$ & Group 1 & Sedimentary & $21 / 10$ \\
\hline Nyker & DR 389 & DK Bh 31 & $\operatorname{Pr} 3$ & $\begin{array}{l}\text { Possibly the same } \\
\text { carvers as in DR } 372 \text {, } \\
379,380 \text { and } 387\end{array}$ & Group 1 & Sedimentary & $26 / 17$ \\
\hline Østermarie 2 & DR 391 & DK Bh 52 & RAK & $\begin{array}{l}\text { Similar names as in } \\
\text { DR 392, but looks } \\
\text { different }\end{array}$ & Group 2 & Metamorph & $20 / 7$ \\
\hline Østermarie 3 & DR 392 & DK Bh 53 & RAK? & $\begin{array}{l}\text { The same carver as } \\
\text { in DR } 401,402,406 \\
\text { and } 408\end{array}$ & Group 2 & Metamorph & $15 / 16$ \\
\hline Klemensker 4 & DR 402 & DK Bh 4 & $\operatorname{Pr} 2$ & $\begin{array}{l}\text { The same carver as } \\
\text { in DR 392, 401, } 406 \\
\text { and } 408\end{array}$ & Group 2 & Metamorph & $17 / 12$ \\
\hline Klemensker 1 & DR 399 & DK Bh 1 & RAK $^{4}$ & & & Metamorph & $22 / 12$ \\
\hline \multirow[t]{3}{*}{ Knudsker } & & DK Bh 69 & & & & Metamorph & $5 / 5$ \\
\hline & & & & & & $\begin{array}{l}\text { Number of } \\
\text { samples }\end{array}$ & $151 / 102$ \\
\hline & & & & & & Total & 254 \\
\hline
\end{tabular}

${ }^{1}$ According to style groups in Gräslund 2006, here based on SRD.

${ }^{2}$ Based on Jacobsen \& Molte 1942.

${ }^{3}$ Based on Jacobsen and Moltke 1942.

${ }^{4}$ This is not exactly RAK, as there are spiral ornaments.

Table 1. Analysed runestones.

Figure 5. Tree Diagram. Result of Hierarchical Cluster Analysis, Ward's method, Euclidean distances. Drawing: Laila Kitzler Åhfeldt.

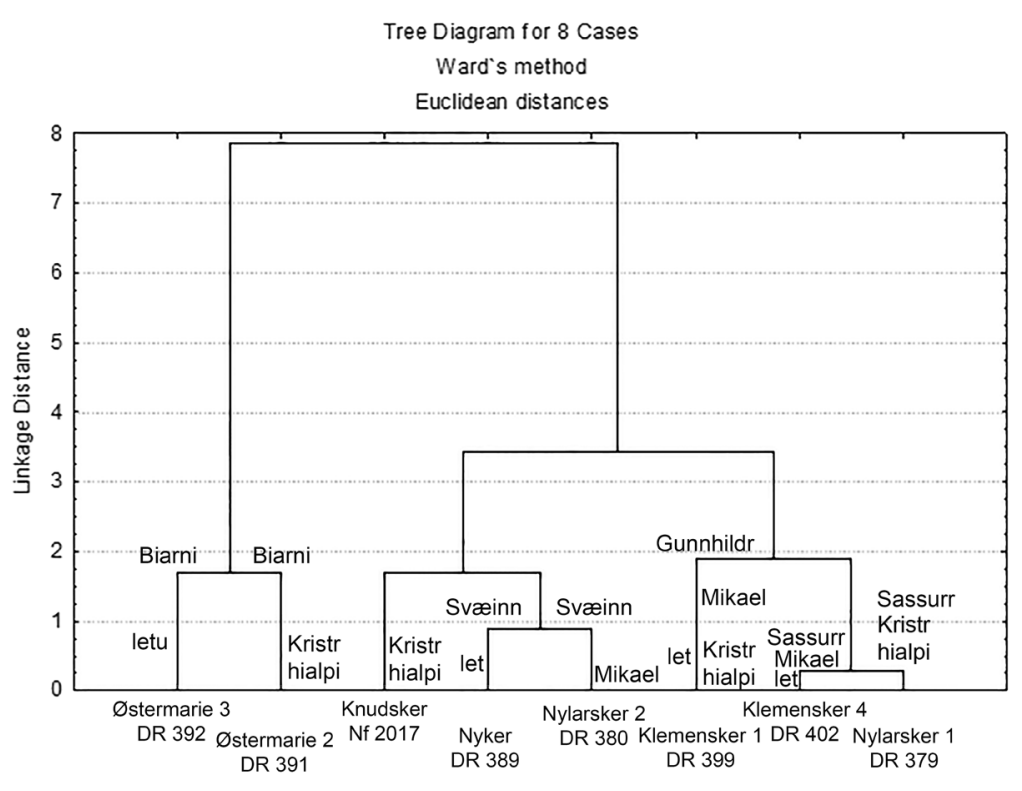




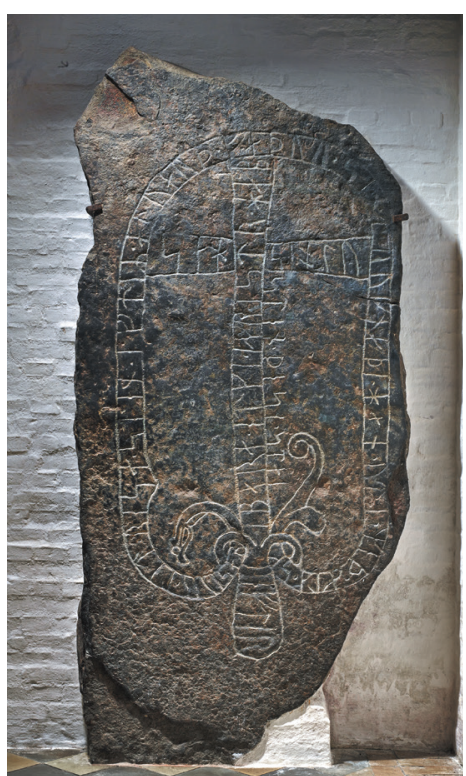

a)

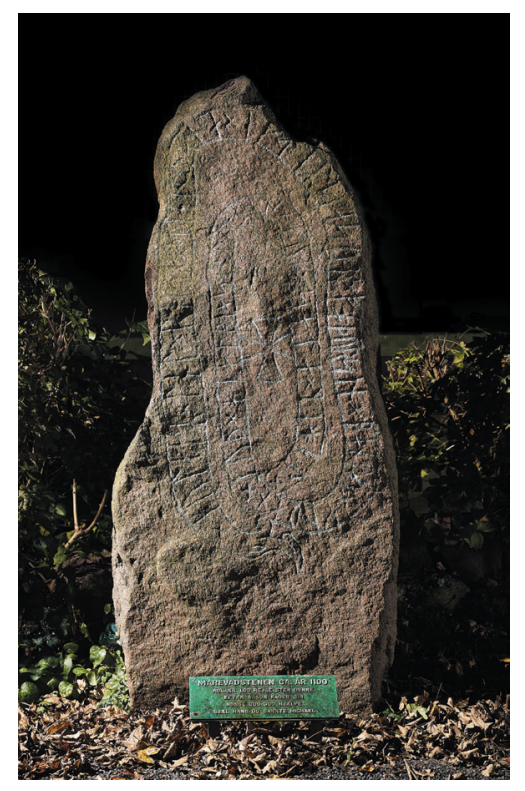

b)

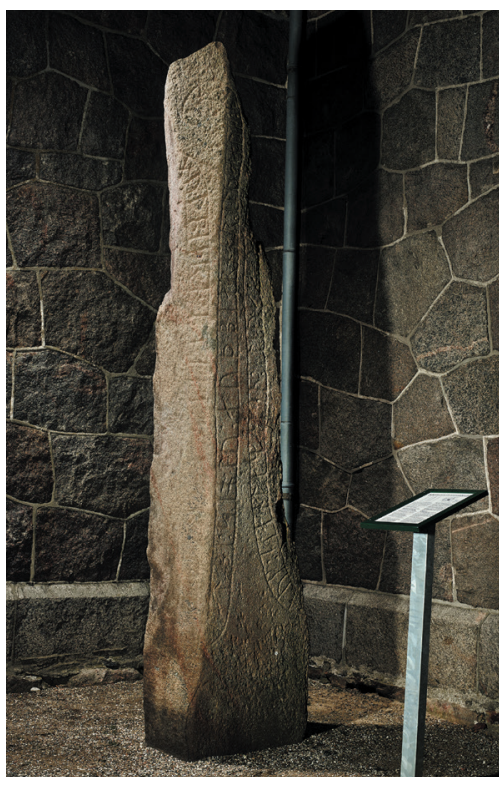

C)

Figure 6. Grouping according to result: Sassur's family. Not in scale. Photo: Roberto Fortuna, National Museum of Denmark CC-BY-SA.

a) Nylarsker 1 (DR 379). Sassurr had the stone raised in memory of Hallvarðr, his father, (who) drowned abroad with all the(?) seamen. May Christ ever(?) help his soul. May this stone stand in memory.

b) Klemensker 4 (DR 402). ØylakR had this stone raised in memory of Sassurr, his father, a good husbandman. May God and Saint Michael help his soul.

c) Klemensker 1 (DR 399). Gunnhildr had this stone raised in memory of Auðbjgrn, her husbandman. May Christ help Auðbjgrn's soul into light and paradise. May Christ and Saint Michael help the souls of Auðbjgrn and Gunnhildr into light and paradise.

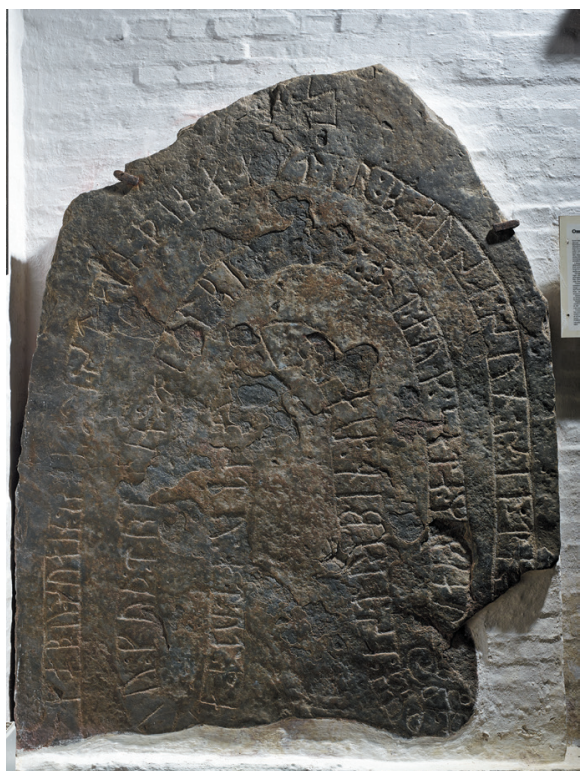

a)

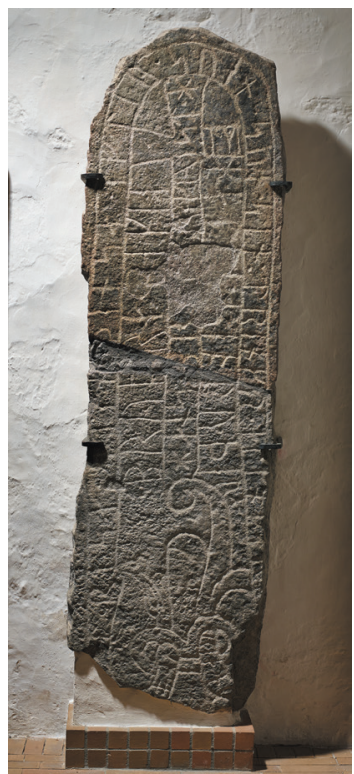

b)

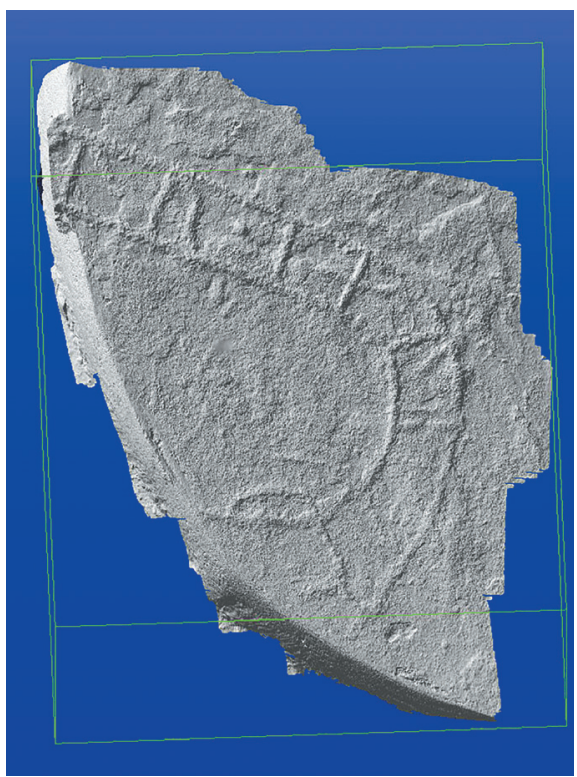

c)

Figure 7. Grouping according to result: Svæinn's family. Not in scale. Photo: Roberto Fortuna, National Museum of Denmark, CC-BY-SA. 3D-image: The new find in St. Knud. 3D-scanning by Teddy Larsson, S3Di; picture by Laila Kitzler Åhfeldt 2017.

a) Nylarsker 2 (DR 380). Svæinn (the Hooded? son of Kāpa?) raised this stone in memory of Bø̄si, his son, a good drængR, who was killed in battle at Ütlengia. May Lord God and Saint Michael help his spirit.

b) Nyker (DR 389). ... had this stone raised in memory of Svæinn, his son. A very good drængR, ...... and (in memory of) his brother. May holy Christ help the souls of both these brothers.

c) Knudsker (DK Bh 69).... May Christ help the soul (?). 


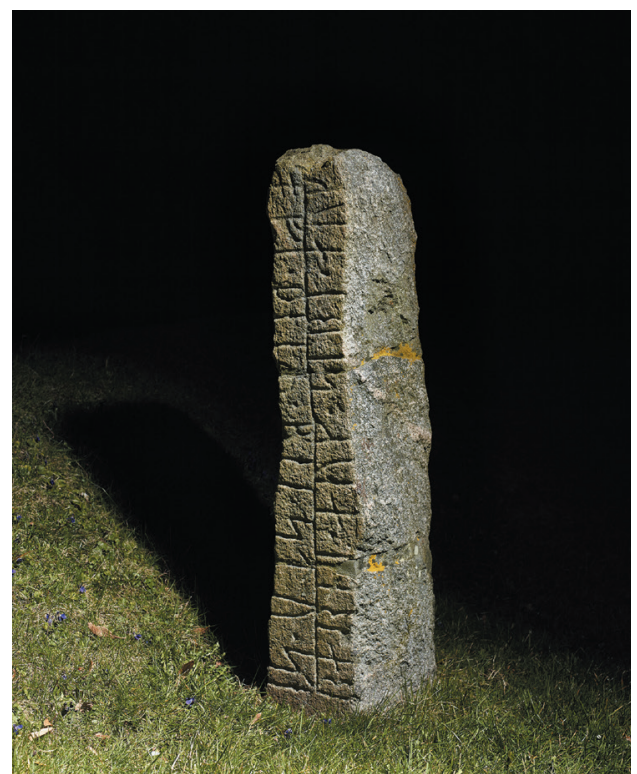

a)

Figure 8. Grouping according to result: Biarni's family. Not in scale. Photo: Roberto Fortuna, National Museum of Denmark, CC-BY-SA.

a) Østermarie 2 (DR 391). Barni/Biarni and Sibbi and Tōfi they raised (the) stone in memory of Ketill, their father, May Christ help his soul.

b) Østermarie 3 (DR 392). Barni/Biarni and Tōfi and Āsgautr had (the) stone raised in memory of Sibbi, their brother. May Christ help (his) soul.

a. DR 379: Sassurr had the stone raised in memory of Hallvarðr, his father ...

b. DR 402: Øylakr had this stone raised in memory of Sassurr, his father...

2) Svæinn is sponsor (DR 380) or son of the sponsor (DR 389). The stone fragment Knudsker is joined to this group (Figure 7).

a. DR 380: Svæinn (OD: Kåbe(?)-Svend; of the hooded cloak? son of K@pa?) raised this stone in memory of Bø̄si, his son...

b. DR 389: ... had this stone raised in memory of Svæinn, his son. A very good drengr, ....... and (in memory of) his brother...

3) Biarni and Tōfi are sponsors, together with Sibbi (DR 391) and Āsgautr (DR 392) respectively (Figure 8).

a. DR 391: Barni/Biarni and Sibbi and Tôfi they raised (the) stone in memory of Ketill, their father...

b. DR 392: Barni/Biarni and Tōfi and Āsgautr had (the) stone raised in memory of Sibbi, their brother...

Our first observation is that the rune carvers have a connection to the sponsor family, here Sassurr's, Svæinn's, and Biarni's families (or families where these names are common). This is to say that the

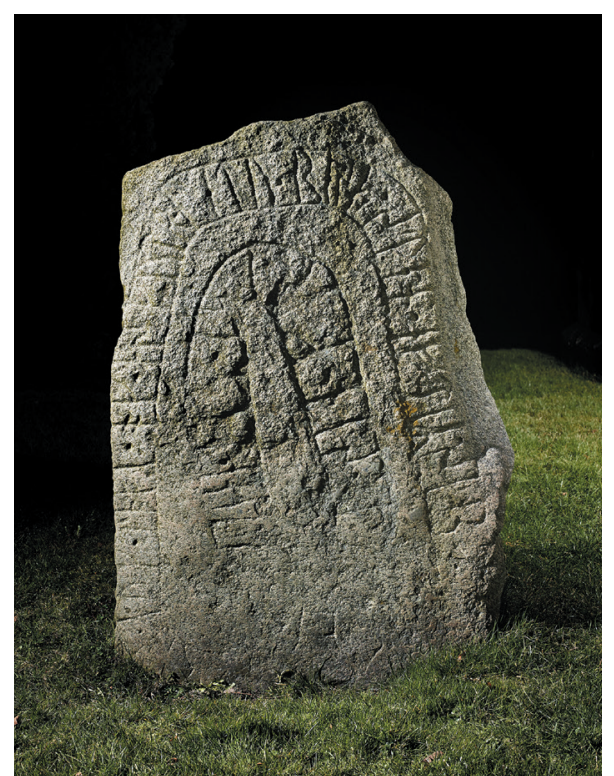

b) pairs of runestones that are most like each other in carving technique are also linked through the names Biarni, Svæinn, and Sassurr. The carving technique on the Gunnhildr stone, Klemensker 1, most resembles the stones of the Sassurr family, but it is hard to determine whether it is the same carver. Knudsker is most similar in its carving technique to the stones of the Svæinn family, but here too it is difficult to ascertain whether it is the same carver.

Nylarsker 1 (Pr 3) was raised by Sassurr, while Klemensker $4(\operatorname{Pr} 2)$ was erected in memory of a Sassurr, but the styles suggest that they were raised in the opposite order. The reason may be a large overlap between the style groups, as is known from elsewhere. It may also be the case that the name Sassurr was passed on from father to son or to the grandson. Although Nylarsker 1 and 2 were both found in Nylars church, and thus possibly were both erected at a nearby place, there is nothing in the carving technique to connect them. Moltke believed that Nylarsker 1, on account of runological, inscriptional, and ornamental similarities, belonged to the same workshop, master, or school as Nylarsker 2 and Nyker (Moltke 1934, 10). This was also discussed at the field runologists' meeting in 2015. Judging by the carving technique, however, Nylarsker 1 belongs to a different group. 
On Østermarie 2 the brother Sibbi is one of those who raised the stone, while on Østermarie 3 he has died. Here too some time has elapsed, but we do not know how long.

For Svæinn too we see this time lapse: on Nylarsker 2 he raises the stone, on Nyker he is dead. Strictly speaking, we do not know that it is the same Svæinn, but the link between these stones as regards the rune carvers may be an argument for it. If so, Svæinn may possibly go under the name Köpu-Svæinn 'Svæinn the Hooded?/son of Kāpa(?)'on Nylarsker 2, while he is called simply Svæinn on Nyker.

Saint Michael is invoked three times, by Svæinn on Nylarsker 2, by Gunnhildr on Klemensker 1 and by Sassurr on Klemensker 4. Did Gunnhildr and Sassurr on the two Klemensker stones have the same carver? If so we may have a weak indication that this carver favoured Saint Michael. In the future it could be interesting to analyse Østerlarsker 2, the fourth runestone that mentions Saint Michael. This is one of several variants of runic prayers for the soul, which Per Beskow believes have their origin in the Christian missions. They have a wide distribution ranging from Denmark to the Mälar basin, even though they are most common in Uppland and on Bornholm (Beskow 1994, 19; see also Zilmer 2013, 134).

On the other hand, there is no link between rune carvers and the prayer kristr hialpi. The prayer that begins kristr hialpi occurs four times, distributed in all the groups. The sponsor formula with the auxiliary verb lata, which has sometimes been considered a high-status marker (Højgaard Holm 2014, 269), occurs in all the groups and is thus not linked to the carver either. In each name group there are runestones both with and without an auxiliary verb in the sponsor formula.

What is interesting about the very fragmentary inscription on Knudsker is that the verb 'help' appears to be spelled ialbi, that is, without the initial $h$. This spelling is rather rare, but it does occur on two other runestones, erected on the other side of the island, namely on Østermarie 1 and Østermarie 3. Østermarie 1 was not $3 \mathrm{D}$-scanned this time, so only future studies can determine whether the two runestones were made by the same carver. But Østermarie 3 was examined as part of this project, and the result shows that Knudsker and Østermarie 3 have some shared regional features but were probably not carved by the same person. On the Bornholm runestones there are also some other examples of loss of $h$, and this is usually regarded as a dialectal feature in the eastern Danish area, since it is also found in some of the Scanian runic inscriptions and manuscripts (Jacobsen and Moltke 1942, 788).

The scanning thus appears to support the interpretation that it is a question of a special dialectal feature, since Østermarie 3 and Knudsker belong to separate groups.

\section{Limitations and Sources of Error}

The tree diagram shows which runestones have the greatest similarities in the grooves. It is very difficult to say, however, whether the groups in the tree diagram from the cluster analysis definitely show different carvers. For cluster analysis there are no general rules for where to cut off the tree, and therefore the interpretation of how many groups there are is partly subjective (Baxter 2016, 63). It can also be a problem that different cluster methods give different results. If there is a real structure, however, different methods ought to give similar results, that is to say, stable clusters (Aldenderfer and Blashfield 1984; Baxter 2016, 68). A common difficulty in the application of cluster methods is the effect of what can be called 'noise', which can be anomalies, small deviant clusters, or cases where membership of a cluster is uncertain, for example, because something could be sorted in more than one cluster. The cluster methods give a sharp assignment to one group, even if there are close alternatives. Here we use Ward's method and Euclidean distances, since that has yielded good results in method studies (Kitzler Åhfeldt 2002). The same experience has been gained in other empirical studies in archaeology, where Ward's method is generally preferred (Baxter 1994). Euclidean distances are better than other distance-calculation methods at recognising non-spherical structures and are less sensitive to anomalies (Baxter 2016, 77).

The result differs slightly from Moltke's grouping according to rune forms and ornamentation. The consequence is that features which, according to Moltke, could belong to a special carver are shared by more than one carver. The new division, however, can be reasonably explained by the rune carvers being connected to the sponsor families. It is impor- 
Figure 9. Distribution of runestones on Bornholm. Map: Rasmus Kruse Andreasen. With permission.

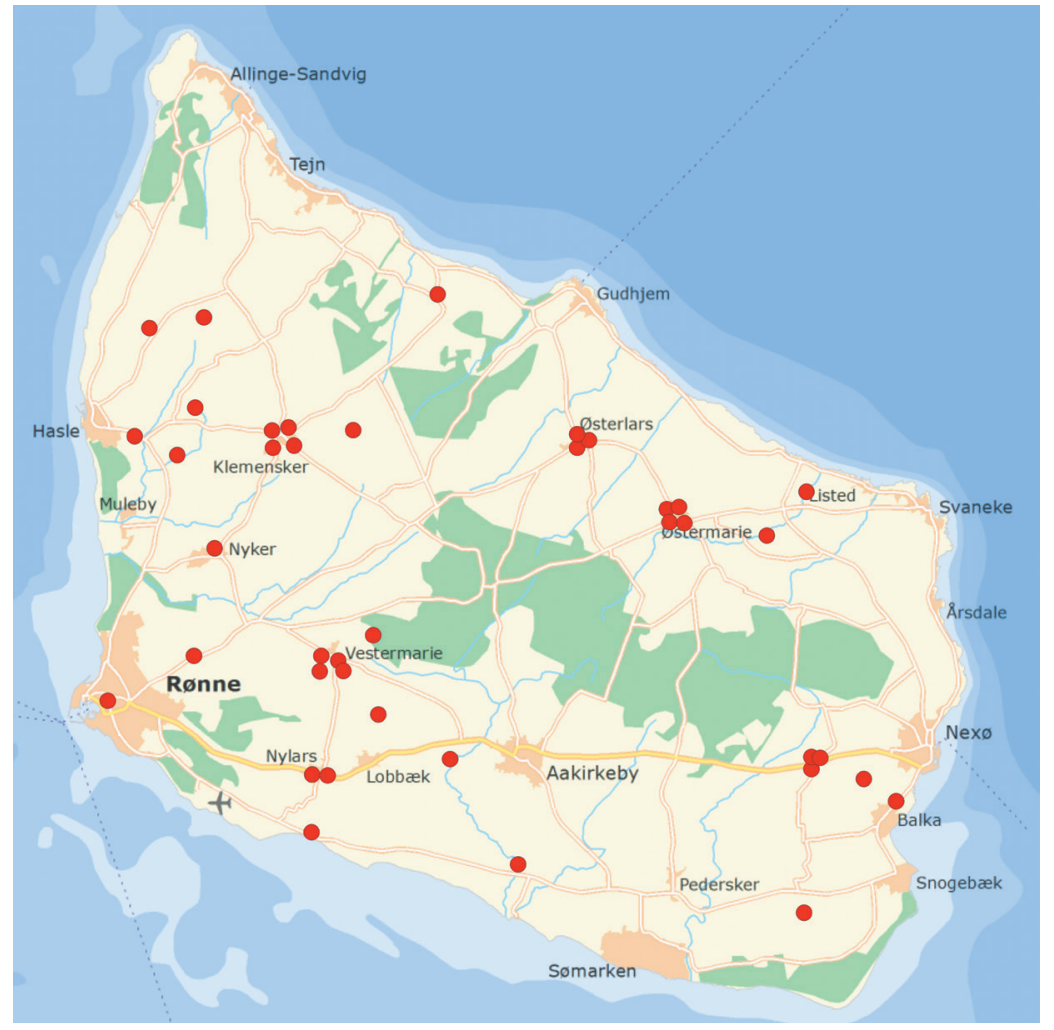

tant to note that both metamorphic and sedimentary rocks occur in the study, but the stratification follows the sponsors, not the rock types.

\section{Discussion}

Among the runestones included in the study we see several features that are often discussed in connection with Bornholm runestones, namely the prayer kristr hialpi, the auxiliary verb lata in the sponsor formula, and the invocation of the archangel $\mathrm{Mi}$ chael. None of these is associated with any of the individual rune carvers, judging by the results of this analysis. These features appear instead to be shared features of Bornholm runestones, or perhaps rather chronological characteristics. The archangel Michael is also mentioned on the Tillitse stone (DR 212) from Lolland, which is dated to the mid eleventh century, and the formula kristr hialpi is used on the Vapnö stone (DR 352) from Halland, presumably with the same dating. The formulae could perhaps be interpreted as a fashion during the eleventh century, best expressed on the Bornholm stones because the runestone custom here was strongest during this period. On the other hand, the carvers appear to be linked to the families that raised the stones, here represented by Sassurr, Svæinn, Biarni, and Gunn- hildr. One can therefore question the claim that the auxiliary verb lata is a status marker. The Bornholm runestones were rather erected by particular families on their own farms, and there seems to have been a flat social structure without a special centre on Bornholm during the late Viking Age and early Middle Ages.

The rune carvers on Bornholm are clearly connected to the families, as is clear from the fact that similarities in carving techniques coincide with the name connections. This means that the technical analyses of the grooves on the runestones fit very well with societal and structural evidence that we have from Bornholm.

The organisational development from the Iron Age to the Viking Age on Bornholm is associated with Sorte Muld, which was the major centre for trade and power in the Iron Age, and one cannot help but wonder whether the king that Bornholm had, according to the merchant Wulfstan around 890 , lived here. Late in the tenth century and at the start of the eleventh, Sorte Muld was reduced to a few individual farms (Aarsleff 2008, 119-120; Watt 2008, 26-27).

After this the settlement structure was different. Single farms popped up all over the island and have later been found by field surveys and metal detector searches. The settlements are characterised by 
features such as Baltic ware, weights, and coins, and they are often found adjacent to the present-day farm (Nielsen 1994, 125-129). As the settlement structure changed, the number of hoards deposited on the island increased, often close to the known settlement units. This suggests that no new powerful trading centre was established on Bornholm after Sorte Muld, and that the island was not ruled by one person. At the same time, the composition of objects and coins in the hoards suggests that Bornholm was an independent economic unit in the Baltic Sea in the eleventh century, which had closer links with Scania and the Slavic lands than with the rest of Denmark (Ingvardson 2010, 334-345).

It is against this societal background that one should view the growth of the runestone custom on Bornholm. Today a large share of Bornholm's runestones are gathered in and around the island's churches, but this current distribution bears little resemblance to where the runestones originally stood. It is characteristic of Bornholm's runestones that there is no sure evidence of their original places. More than half have been found at the churches, where they have either been discovered in the churchyard or are walled into the churches. Some of them might possibly have stood at the churches from the beginning, if the churches were built at the site of larger farms or earlier burial grounds. But almost half have been found as parts of bridges over rivers or at fords, or associated with the single farms that appeared on the island in the course of the late Viking Age or early Middle Ages. This sketch of the distribution of runestones shows a picture of the finds which is as scattered as a map of the island's hoards and the late Viking-Age and early medieval settlement (Figure 9). It is possible that some of the runestones can be linked to the documented settlement remains, for example, Åker 1, also called the Grødby stone, with a find history going back to Ole Worm's time, when according to the priest's report it was 'In Grødby at Jørgen Vdi's farm', and Worm informs us that it was placed in a bridge that was called 'Runebroe' or Rune Bridge. Later the stone fell into oblivion, but it was found again in 1819, then in Grødby bridge south of Akirkeby and west of Pedersker (Jacobsen and Moltke 1942, 423). Grødbygård is one of the farms in Åker parish with roots going all the way back to the late Viking Age and early Middle Ages (Nielsen 1994, 127). The same pattern applies to Klemensker 1 and 4, which are dealt with in this article. Klemensker 1 was laid over a stream close to Brogård (Jacobsen and Moltke 1942, 457-458). Brogård likewise goes back to the late Viking Age and early Middle Ages (Nielsen 1994, 127). And Klemensker 4, which is also called the Marevad stone, was built into the bridge over a stream between the lands of Marevad and Pilegaard (Jacobsen and Moltke 1942, 461). Pilegaard too has roots in the late Viking Age and early Middle Ages. It is therefore not unreasonable to assume that many runestones originally had a central location at the single farms that popped up during the eleventh century.

When one follows this line of thought it is natural that the rune carvers are linked to the individual families and perhaps can even be found as members of the families. This strengthens an earlier proposal that the carvers can be seen as representatives of their households and their connections may reflect the social networks of their families (Kitzler Åhfeldt 2015). We have here a decentralised society, where power was in the hands of the separate families. Trade was pursued on the individual farms, and wealth was amassed within the individual family. This also accords well with the fact that we rarely find titles like retainers or estate-stewards among the runestones on Bornholm, because such professions were unnecessary in a family-based society. The many hoards may indicate that Bornholm was especially vulnerable to plundering (Ingvardson 2010), which presumably is also a sign that power was divided between many people, each seeking their own protection.

On Bornholm, then, there was no professional rune carver who travelled around with commissions to carve runestones. Although there was a certain consensus about form and style in eleventh-century runestones, the runestones are also expressions of the decentralised structure. This suggests some exciting perspectives concerning who could carve runes at the end of the Viking Age and the start of the Early Middle Ages. 


\section{Conclusion}

The above studies suggest that the carvers of the runestones should be sought within the individual families. We do not know how many wealthy families there were on Bornholm during this period, but the many single farms, the hoards, and the relatively large number of runestones distributed over the whole island indicate that there were quite a few. If we reckon, as the analyses suggest, that there was at least one rune carver in every family, we have indirect evidence that the culture of runic writing was more widespread at the start of the Middle Ages than we have hitherto assumed - regardless of the fact that the inscriptions are primarily preserved on stone. One can also discuss, further, whether the rune carvers were the only individuals in each family who knew runes, or if it was a part of a person's cultural education to learn to read and write runes. In any case, the analyses suggest that there was no need for help from outside to carve runes, neither in the Viking Age nor later.

The analyses have shown that the Bornholm rune carvers were linked to particular families, and that the individual rune carvers were following the different fashion currents of the time. One can possibly envisage contacts on a personal level with rune carvers from central Sweden, through reciprocal visits and travels, in view of the fact that comparisons between carving techniques on Bornholm's runestones and areas such as Öland, Gotland, and mainland Sweden appear to indicate Södermanland as particularly interesting (Kitzler Åhfeldt 2019). In our opinion, however, cooperation between rune carvers need not have any connection whatever to either royal power or the unification of kingdoms. We have also shown that the individual families can perhaps be linked to some of the single farms that grew up on Bornholm in the late Viking Age and early Middle Ages, replacing the previous highly centralised societal structure.
Perhaps Gunnhildr, Auðbjgrn, and their family, known from Klemensker 1, lived at Brogård, while Sassurr and his family lived at Pilegård in Klemensker parish. Future studies may show whether the same pattern can be seen for other Bornholm runestones which can be grouped together by virtue of associated names. If so, we see a Bornholm society that differed noticeably from the results we know from studies of Swedish runestones.

\section{Acknowledgements}

We wish to thank Finn Ole Nielsen and Bornholm's Museum for their kind hospitality and professional advice during fieldwork, Alan Crozier for translation of this article to English and the anonymous reviewers for helpful comments.

\section{Funding details}

This work was supported by Riksbankens jubileumsfond, The Royal Swedish Academy of Letters, History and Antiquities and the Swedish National Heritage Board under SAF16-0359:1 within the project Everlasting Runes: a research platform for Sweden's runic inscriptions.

\section{Notes}

1. This workshop, named Relations and Runes: The Baltic Islands and their interactions during the Late Iron Age and Early Middle Ages, was a joint venture between the research projects 'Everlasting Runes: A digital research platform for Sweden's runic inscriptions' and 'The Viking Phenomenon'.

2. The Groove Measure function in DeskArtes Design Expert, along with special calculation templates.

\section{Bibliography}

Aarsleff, E. 2008. Fund fra vikingetiden. In: C. Adamsen, U. Lund Hansen, F. O. Nielsen and M. Watt, eds. Sorte Muld. Rønne: Bornholms Museum, 119-121.

Aldenderfer, M. S., and Blashfield, R. K. 1984. Cluster Analysis. Beverly Hills: Sage. 
Andersen, L. S. 1992. Runesten på Bornholm: bevaringsarbejdet 1986-1990. Hørsholm: Miljøministeriet, Skov- og Naturstyrelsen.

Baxter, M. 1994. Exploratory multivariate analysis in archaeology. Edinburgh: Edinburgh University Press.

Baxter, M. 2016. Multivariate Analysis of Archaeometric Data: An Introduction. Nottingham.

Beskow, P. 1994. Runor och liturgi. In: P. Beskow \& R. Staats, eds. Nordens kristnande i europeiskt perspektiv. Occasional Paper on Medieval Topics 7. Skara: Viktoria Bokförlag, 16-36.

Bæksted, A. 1935. Vester Marie-stenen I og de danske Runeligsten. Danske Studier 1935, 39-58.

$\mathrm{DK} \mathrm{Bh}+\mathrm{nr}=$ entry number in Danske Runeindskrifter, at database hosted at http://runer.ku.dk.

$\mathrm{DR}+\mathrm{nr}=$ signum in Danmarks Runeindskrifter, L. Jacobsen and E. Moltke. 1941-1942. Copenhagen: Munksgaard.

Danske Runeindskrifter. Database. Available from http://runer.ku.dk/ [Accessed 10 April 2018].

Eilsøe, L. 2017. Interview with Lisbeth Imer 27 September 2017. Ny runesten har ligget for øjnene af alle i 900 år. Available from https://www.dr.dk/nyheder/regionale/bornholm/ny-runesten-har-ligget-oejnene-af-alle-i-900-aar [Accessed 28 September 2017].

Everitt, B. S., Landau, S., Leese, M.and Stahl, D. 2011. Cluster Analysis $5^{\text {th }}$ edition. Hoboken: Wiley. https://doi.org/10.1002/9780470977811.

Gelting, M. H. 2012. Lund, Dalby og Bornholm: politik og mission i biskop Eginos tid. In: S. Borgehammar \& J. Wienberg, eds. Locus Celebris: Dalby kyrka, kloster och gård. Lund Centrum för Danmarksstudier \& Göteborg: Makadam förlag, 101-111.

Gräslund, A.-S. 2006. Dating the Swedish Viking-Age rune stones on stylistic grounds. In: M. Stoklund, M. Lerche Nielsen, B. Holmberg and G. Fellows-Jensen, eds. Runes and Their Secrets: Studies in Runology. Copenhagen: Museum Tusculanum Press, 117-139. https://doi.org/10.1163/9789042032118_026

Gräslund, A.-S. 2016. Recension av Danmarks runesten: En fortelling, av Lisbeth M. Imer och Roberto Fortuna (Copenhagen 2016). Futhark, 7, 181-185. https://doi.org/10.33063/issn/1892-0950.

von Heijne, C. 2004. Särpräglat. Vikingatida och tidigmedeltida myntfynd frän Danmark, Skäne, Blekinge och Halland ca 800-1130. Stockholm Studies in Archaeology 31. Stockholm: Stockholms universitet.

Højgaard Holm, L. 2014. De bornholmske runesten og deres inskrifter. Bornholmske Samlinger, Række IV, Bind 8, 260-299.

Horsnæs, H. W. 2013. Crossing Boundaries: An Analysis of Roman Coins in Danish Contexts. Vol. 2, Finds from Bornholm. Copenhagen: National Museum of Denmark.

Imer, L. M. 2015. The Danish runestones - when and where? Danish Journal of Archaeology, 4, 164-174. https://doi.org/10.1080/21662282.2015.1104905. 
Imer, L. M. 2016. Danmarks runesten: En fortalling. Foto: Roberto Fortuna. Copenhagen: Gyldendal.

Imer, L. M. and Kitzler Åhfeldt, L. Forthcoming. Knudsker-stenen. Erkendelsen af en runesten. Nationalmuseets Arbejdsmark 2019.

Imer, L. M. and Steenholt Olesen, R. 2018. In the beginning was the Word...new finds of lead amulets in Denmark. In: A. Bauer, E. Kleivane, Elise \& T. Spurkland, eds. Epigraphy in an intermedial context. Dublin: Four Courts, 123-155

Ingvardson, G. T. 2010. Møntbrug: Fra vikingetid til vendertogter. Aarhus: Aarhus Universitetsforlag.

Ingvardson, G. T. 2014. Trade and Power - Bornholm in the Late Viking Age. In: H. C. Gulløv, ed. Northern Worlds - landscapes, interactions and dynamics. Research at the National Museum of Denmark. Odense: University Press of Southern Denmark, 325-337.

Jacobsen, L. and Moltke, E. 1942. Danmarks Runeindskrifter: Text. Copenhagen: Munksgaard.

Kitzler Åhfeldt, L. 2002. Laser Scanner Analysis of Viking Age Rune Stones. Theses and Papers in Scientific Archaeology B:9. Stockholm: Archaeological Research Laboratory.

Kitzler Åhfeldt, L. 2012. Carving technique and runic literacy. In: K. Zilmer and J. Jesch, eds. Epigraphic Literacy and Christian Identity: Modes of Written Discourse in the Newly Christian European North. Utrecht Studies in Medieval Literacy 4. Turnhout: Brepols, 63-97.

Kitzler Åhfeldt, L. 2015. Rune Carvers and Local Mobility. Viking and Medieval Scandinavia, 11, 143-182. https://doi.org/10.1484/j.vms.5.109602.

Kitzler Åhfeldt, L. 2016. Åsmund Kåresson: en sällskaplig runristare. Situne dei 2016, 26-39.

Kitzler Åhfeldt, L. 2017. Nytt runfynd avslöjat genom 3D-skanning. Available from http://www.k-blogg. se: http://www.k-blogg.se/2017/09/28/nytt-runfynd-avslojat-genom-3d-skanning/ [Accessed in 28 September 2017].

Kitzler Åhfeldt, L. 2019. Provenancing Rune Carvers on Bornholm through 3D-Scanning and Multivariate Statistics of the Carving Technique. European Journal of Archaeology, 1-23.

https://doi.org/10.1017/eaa.2019.37.

Kristensen, M. 1930. En Opkaldelsesskik på svenske og bornholmske Runestene. Danske Studier 1935, 150156.

Lerche Nielsen, M. 1994. Det danske runemateriales personnavneforråd. G. Fellows-Jensen and B. Holmberg (red.) Vikingetidens sted-ogpersonnavne. Rapport fra NORNAs 22. symposium i København 14.-16. januar 1993. NORNA-rapporter 54. Uppsala: NORNA-förlag, 165-185.

Lerche Nielsen, M. 1997. Vikingetidens personnavne i Danmark: belyst gennem runeindskrifternes personnavne og stednavne på torp sammensat med personnavneforled. Copenhagen: University of Copenhagen.

Lihammer, A. 2007. Bortom riksbildningen: Människor, landskap och makt i sydöstra Skandinavien. Lund Studies in Historical Archaeology 7. Lund: Institutionen för arkeologi och antikens historia. 
Moltke, E. 1934. Vester Marie-stenen VI og lidt om svensk Indflydelse på bornholmske Runestene. Danske studier 1934, 9-20.

Moltke, E. 1976. Runerne i Danmark og deres Oprindelse. $1^{\text {st }}$ ed. Copenhagen: Forum.

Moltke, E. 1985. Runes and Their Origin - Denmark and Elsewhere. Copenhagen: Nationalmuseets forlag.

Nielsen, F. O. 1994. Middelaldergårde på Bornholm. Hikuin, 21, 125-138.

Nielsen, F. O. 1998. Middelalderens Bornholm. Rønne: Bornholms amt.

Norn, O, Schultz, C. G., and Skov, E. 1954. Danmarks Kirker volume VII, Bornholm. Copenhagen: Nationalmuseet.

Ög + number $=$ inscription published in Östergötlands runinskrifter, i.e. SRI, 2.

Öl + number $=$ inscription published in Ölands runindskrifter, i.e. SRI, 1.

Olsen, M. 1906. De skaanske og bornholmske Runestene. Danske Studier 1906, 20-39.

Randsborg, K. 1980. The Viking Age in Denmark: The Formation of a State. New York: St. Martin's Press.

SRD $=$ Samnordisk runtextdatabas. Version 3.0. Available from

http://www.nordiska.uu.se/forskn/samnord.htm. Date of text file 24 March 2015 [Accessed in 31 May 2017].

SRI = Sveriges runinskrifter. Various authors; published by Kungl. Vitterhets Historie och Antikvitets Akademien. 14 vols. Stockholm, 1900-.

SRI, 1 = Ölands runindskrifter, by Sven Söderberg and Erik Brathe. 1900-1906.

SRI, 2 = Östergötlands runinskrifter, by Erik Brate. 1911-18.

SRI, 6-9 = Upplands runinskrifter, by Sven B. F. Jansson and Elias Wessén. 1940-58.

Stoklund, M. 1991. Runesten, kronologi og samfundsrekonstruktion. Nogle kritiske overvejelser med udgangspunkt i runestenene i Mammenområdet. In: M. Iversen, ed. Mammen. Grav, kunst og samfund i vikingetid. Århus: Århus Universitetsforlag, 285-297.

Stoklund, M. 2006. Chronology and typology of the Danish runic inscriptions. In: M. Stoklund, M. Lerche Nielsen, B. Holmberg and G. Fellows-Jensen, eds. Runes and Their Secrets: Studies in Runology. Copenhagen: Museum Tusculanum Press, 355-383. https://doi.org/10.1163/9789042032118_026.

Svanberg, F. 2003. Decolonizing the Viking Age 1. Acta Archaeologica Lundensia. Series in $8^{\circ}$. No. 43. Stockholm; Almqvist \& Wiksell International.

$\mathrm{U}+$ number $=$ inscription published in Upplands runinskrifter, i.e. SRI, 6-9. 
Wagnkilde, H. and Pind, T. 1991. En gravplads ved Ndr. Grødbygård i Åker. Bornholms Museum, 19891990, 53-66.

Watt, M. 1983. Huse og grave fra vikingetid ved Runegård i Grödby. Bornholms Museum, 1982, 25-34.

Watt, M. 1985. En gravplads fra sen vikingetid ved Runegård, Åker. Bornholms Museum, 1984-1985, 77 100 .

Watt, M. 2008. Sorte Muld - Past and Present. In: C. Adamsen, U. Lund Hansen, F. O. Nielsen and M. Watt, eds. Sorte Muld. Rønne: Bornholms Museum, 12-27.

Wienberg, J. 1986. Bornholms kirker i den ældre middelalder. Hikuin, 12, 45-66.

Wimmer, L. F. 1905. De danske Runemindesmarker. Bd 3, Runestenene i Skåne og på Bornholm. Copenhagen.

Zilmer, K. 2013. Christian Prayers and Invocations in Scandinavian Runic Inscriptions from the Viking Age and Middle Ages. Futhark, 4, 129-171. https://doi.org/10.1484/m.usml-eb.5.100474. 